\title{
Early Load-Induced Fracturing in a Prograding Carbonate Margin
}

\author{
Donald F. McNeill and Gregor P. Eberli \\ Comparative Sedimentology Laboratory \\ Marine Geology and Geophysics, University of Miami \\ 4600 Rickenbacker Causeway, Miami, Florida 33149 USA \\ dmcneill@rsmas.miami.edu
}

\begin{abstract}
The description of early non-tectonic fracturing of carbonates is rare because (1) fractures in young carbonates occur in areas not easily accessible, and (2) burial and diagenesis often precludes the determination of the exact timing of (early) fracturing in older rocks. The Bahamas Drilling Project core Clino recovered the upper part of a young prograding platform margin containing a set of fractures interpreted to be non-tectonic; formed by rapid loading of a clinothem package. Three intervals with open and partially infilled fractures were recovered in Clino, and those fractures are closely related to the lithologic variation in the slope sediments. Fracturing occurred specifically within coarse, well-cemented skeletal deposits. These coarser deposits are generally margin-derived sediments within the background sediment. The overlying and underlying finer-grained sediments are significantly less fractured. The fractures occur within a 45 m thick interval immediately below a surface of non-deposition or erosion with a hiatus of $>0.5 \mathrm{my}$. Our model suggests that early cementation of the skeletal sands, followed by rapid margin progradation, provided significant load to generate brittle fracturing (shear and extensional) in lithified strata. Laboratory deformation experiments, magnetic fracture-plane orientation and the timing of load emplacement are consistent with load-induced fracturing. Fracture planes preferentially dip westward which is parallel to the depositional slope. Similar early fracture porosity can act as high permeability conduits for diagenetic fluids and hydrocarbons in platform margin and slope strata.
\end{abstract}

\section{Introduction}

Early fracturing of lithified carbonates is a rarely reported phenomenon. Observation of fractures in young carbonates is difficult because such features generally occur in relatively inaccessible near-surface settings. In older rocks, burial and diagenetic history may preclude the identification and the exact timing of fracturing, making it difficult to determine that fracturing occurred early. The Bahamas Drilling Project core Clino recovered, for the first time, a complete section of a 
young (Neogene) prograding platform margin along the western margin of Great Bahama Bank (Figure 1). This core recovered a set of fractures in the clinothem package, and they are described here. These fractures are natural and clearly not drilling induced (Kulander et al., 1990). Our interpretation of the fractures benefits greatly from existing studies. A detailed lithologic (Kenter et al., 2001), stratigraphic (McNeill et al., 2001; Eberli et al., 2001) and diagenetic (Swart et al., 2001; Melim et al., 2001) framework has been produced for core Clino. This extensive dataset allows a comprehensive evaluation of the conditions that contributed to early rock fracturing. The objectives of this paper are to use the fracture inclination, fracture orientation, fracture density and constraints on fracture timing to illustrate a mechanism of early fracturing. Our hypothesis relates early diagenesis and rapid progradation of the platform margin to invoke fracturing. The mechanism of early fracturing in our model has implications for preferential fluid exchange and might be a contributing factor in the collapse of platform margins (Hine et al., 1992).

\section{Stratigraphic Setting of the Fracture Interval}

Three intervals of open and partially infilled fractures were recovered in core Clino within midPliocene seismic sequences $e$ and $f$, just below their respective seismic sequence boundaries (SSB) D and E (Figure 2) (see Eberli et al., 2001 for a description of the seismic units and sequences). In these two sequences, core Clino penetrated the relatively steep $\left(\sim 4^{\circ}\right)$ part of the prograding clinoform (Eberli \& Ginsburg, 1987). The two main fracture intervals (upper and middle) are within sequence $e$, and a third, thin fracture interval (lower) is at the top of sequence $f$ (Figure 2). The SSB-D and a disconformity just above it, represent an interval of non-deposition and/or erosion with a duration of about 0.5 to 0.8 my. Above SSB-D, a $\sim 275 \mathrm{~m}$ thick package of sediment associated with prograding sequence $d$ was deposited in a period of between 0.1 and 0.2 my. The three fractured intervals are closely tied to the lithologic variation in the slope sediments. The majority of fractures (upper and middle interval) occur specifically within coarse, well-cemented skeletal deposits. These skeletal deposits, termed "interruptions" by Kenter et al. (2001), represent margin-derived sediments deposited within (or interrupting) the background platform-derived sediment. The sediment "interruption" beds are interpreted by Kenter et al. (2001) as transported to the slope during times when most of the platform was subaerially exposed. The overlying and underlying finer-grained hemipelagic or 'background" sediments that are shed to slope during times of platform flooding and high sedimentation rates are generally less indurated and contain less fractures. Seismic sequence $e$ represents sediments deposited during a major backstep of the platform margin (to the east) and a period of platform aggradation 
(McNeill, 2005). The slightly coarser grain-size likely promoted more rapid cementation relative to the finer-grained, and less permeable hemipelagic sediments (Westphal \& Munnecke, 1997; Kenter et al., 2001). This preferential early cementation is also supported by rock magnetic studies on the fractured and non-fractured interval, where (very) early cementation appears to have preserved chains of magnetite crystal from magnetotactic bacteria (McNeill, 1997).

\section{Methods}

\section{Core Data and Fracture Characterization}

The high core recovery ( $>90 \%$ ) in the middle and lower parts of core Clino provide a nearly continuous record of early diagenetic features such as the fractures we report here. One-third of the whole core (6.3 cm diameter) was cut and separated for archive purposes. The remaining two-thirds of the core was used to measure and to collect samples. The depth values reported here are consistent with those in Ginsburg (2001), where the depths are in metres below mud pit (subtract $7.3 \mathrm{~m}$ to obtain depth below mean sea level). The depth interval from about 375 to 450 $\mathrm{m}$ contains distinct fractures that were first noted on site during drilling. The fractures in the slabbed core were characterized by measuring fracture plane inclination, fracture length, fracture aperture, and noting if the fracture was open or filled. The vertical extent of the fracture was also recorded and was used to provide a rough estimate of total fracture length per metre of core. This calculation is used to approximate fracture density.

\section{Fracture Orientation}

The dip azimuth of the fracture plane was calculated using magnetic declination. This procedure consisted of measuring the fracture dip orientation relative to an arbitrary red line marked on the core (used to confirm the up direction). The offset angle of the red line was then measured relative to a paleomagnetic plug drilled from that piece of core. The declination direction measured from the plug (see McNeill et al., 2001) was then used to reorient the core piece (red line), and calculate the true dip azimuth of the fracture plane. This reorientation method is fairly robust given the strength and stability of the magnetic signal in this section of the core (McNeill et al., 1997; McNeill et al., 2001). This method does, however, have a certain amount of inherent error (such as magnetometer error, least-squares calculation of declination, preservation of true declination), and the error range is estimated at $\pm 5^{\circ}$. All of the orientation data are from pieces of 
core that contain either a magnetic plug sample or are from adjacent pieces that could be fitted together with a plug-oriented core piece.

\section{Sr-Isotope Ratio on Fracture Fill}

A single strontium-isotope ratio on the mineralized fill material (celestite) was obtained by Peter Swart and provided for this study. This data point followed the methodology described by Swart et al. (2001) for the strontium-isotope stratigraphy of core Clino material. The celestite value was normalized to a NIST-987 standard of 0.710248 and the age determined by the look-up table of McArthur et al. (2001), which is calibrated to the Berggren et al. (1995) timescale.

\section{Uniaxial Deformation Experiments}

To obtain an estimate of the force needed to fracture rock of similar composition to that which hosts the fractures, two uniaxial compression tests were conducted. Two whole-core samples from the fractured zone (440 and $447 \mathrm{~m}$ ) were subjected to compression tests at ETH-Zurich. The effective pressure of brittle failure was determined with standard methods of comparing the confining pressure minus the pore pressure (water at $10 \mathrm{MPa}$ ). The nature of the fracture and fault produced was also recorded.

\section{Results}

\section{Fracture Data Set}

The fractures in core Clino were grouped into three classes: through-going shear, axial split, or cataclastic shear (following the usage of Paterson, 1978). The through-going shear type was often a simple, single fracture or fault with relatively little effect on the adjacent host sediment (Figure 3a,b). The axial fractures are those oriented vertically or near vertically $\left(>70^{\circ}\right)$ along the axis of the core (Figure 3c). This type often had multiple fractures that radiated outward from a slightly larger central fracture, although it was difficult to trace these subfractures in a $6.3 \mathrm{~cm}$ wide core. The cataclastic shear fracture type showed a zone, 10-20 cm long, that contained abundant fractures of differing orientations, lengths and aperture sizes (Figure 3d,e). The cataclastic zones sometimes had a central through-going fracture surrounded by subfractures, or terminated abruptly on a bed of differing composition and integrity. 
The inclination of the fractures $(n=151)$ showed a skewed distribution, with most fractures biased to higher angles between $30^{\circ}$ and vertical (Figure 4). The mean inclination was $\sim 57^{\circ}$, with a large standard deviation $\left(\sim 24^{\circ}\right)$. The fracture inclination with depth in each of the intervals shows a broad scatter of values (Figure 5). It is interesting to note that the two intervening hemipelagic intervals between the three fracture intervals do contain several fractures, and that these fractures are very steep to vertical. Unlike the fracture inclination with depth, the cumulative fracture length (total fracture length in centimetres per $3 \mathrm{~m}$ interval) does show a generally higher fracture density near the tops of the three intervals and a trend of decrease downward (poorly defined) (Figure 6).

\section{Host Rock Lithology, Log Signature, and Fracture Fill}

The two main fracture intervals are hosted by the well-cemented skeletal grainstones and packstone units, termed "interruptions" and derived from the shallow platform to the east. The differential cementation between the fracture-host sediment and the hemipelagic sediments is well illustrated in the downhole log signature (Figure 7). The cemented skeletal intervals tend to show a higher sonic velocity relative to the background hemipelagic intervals. Similarly, the caliper log across the fractured intervals shows borehole diameters very close to the size of the diamond core bit, whereas the hemipelagic units above, within and below the cemented skeletal intervals show larger diameters due to less cementation (Figure 7). Within the fracture intervals, both the sonic and caliper logs show high frequency variations, a signature that likely reflects the variability of fracture-derived porosity and density.

The more intensely fractured rock in the middle and upper intervals sometimes contain secondary mineralization in the form of celestite (Melim et al., 2001)( $\mathrm{SrSO}_{4}$ also known as celestine, Figure 3f). The infill of fractures by celestite is highly variable with respect to depth and aperture size. In some cases, celestite has nearly filled the fracture (see Figure 3e), while in some of the larger fractures elongate individual celestite crystal are found lining the fracture surface (as in Figure 3f). The celestite infill clearly demonstrates the natural origin of these fractures. The timing of the celestite infill can be only poorly constrained. A celestite crystal at $\sim 386$ m produced a Srisotope ratio with an age range of 1.34-2.15 Ma. The uncertainty is high for this age as the time of crystallization due to the two possible origins of the strontium; either from dissolution of the aragonite or from seawater entering the platform. Most likely, it is some combination of the two, as Melim et al. (2001) suggest a temporal overlap of celestite precipitation and aragonite 
neomorphism. They also argue that abundant celestite precipitation would require the import of sulphate by active fluid circulation. Even with the temporal uncertainty, it is interesting to note that the celestite age is coincident with the end of a major progradational pulse in the latest Pliocene (see Discussion below).

\section{Fracture Orientation}

The dip azimuth of 19 through-going shear fractures, determined using magnetic declination, shows a bi-directional, conjugate distribution (Figure 8). Two general groupings are approximately $180^{\circ}$ apart, one westward and one eastward. These two orientations are roughly equivalent to seaward (west) and bankward (east) of the bank margin (oriented just east of north). The majority of the fracture planes dip to the west (14 of 19) in the direction of the depositional slope and basin.

\section{Discussion of Fracture Origin}

\section{Origin of the Fractures: A Loading Model}

The origin of the fractures is clearly not related to drilling (as celestite partly infills many fractures), and there is no evidence of local tectonic forces that could generate such localized fractures. Several key features and lines of evidence (shear/cataclastic fracture type, steep angle, conjugate fracture sets orientated perpendicular to the margin, and downward cumulative fracture length) suggest that fracture formation is related to vertical compression from sediment loading. Our model for fracture formation involves several factors: the integration of the coarse, permeable skeletal sand "interruptions", a prolonged period of non-deposition or erosion associated with a sequence boundary, and the subsequent rapid deposition of overlying sediment related to clinothem progradation (Figure 9). The fractures occur within a $45 \mathrm{~m}$ thick interval immediately below a non-depositional surface (SSB-D). This period of non-deposition (3.5-3.0 Ma) may have promoted cementation within the skeletal sediments of sequence $e$ and at the top of sequence f. Malone et al. (2001) dated similar Quaternary "lowstand” deposits and corroborated the interpretation that the better cemented coarser-grained slope deposits are indeed deposited during times of lowered sea level and reduced sedimentation rates. The circulation of seawater through the permeable skeletal "interruptions" likely promoted lithification relative to the less permeable and finer-grained hemipelagic "background” sediments. The onset of platform progradation in the late Pliocene rapidly loaded the partially cemented "interruption" intervals 
and promoted shear and extensional fracturing (see model summarized in Figure 10).

Experimental rock mechanics has shown that compressional loading can produce conjugate shear fractures with inclinations ranging from $40^{\circ}$ to $70^{\circ}$, as well as near vertical extensional (axial splitting) fractures. The inclinations of the fracture planes in core Clino are generally consistent with the features generated from laboratory experiments.

\section{Laboratory Support for Loading and Early Fracturing}

Uniaxial deformation experiments of the two Clino "interruption" samples (at a depth of 440 and $447 \mathrm{~m}$ ) showed brittle behavior at laboratory strain rates of 10 MPa (effective pressure). The resultant brittle failure produced a single, steeply inclined, through-going fault (D. Olgaard, personal communication). This brittle fracturing is consistent with the current overburden pressure of a $425 \mathrm{~m}$ rock column (at $2.1 \mathrm{~g} / \mathrm{cc}$ ), within today's depth range of the fractures. If fracturing occurred after the progradation load (275 m column) was emplaced ( $1.5 \mathrm{Ma}$ ) it is reasonable to assume that the "interruption" horizon was at an earlier stage in its lithification history and thus susceptible to early load-induced fracture.

\section{Ancient Analogs for Loading and Early Fracturing}

Documentation of early fracturing on carbonate platform margins is rare. One example from a prograding margin is the Permian, Capitan reef of west Texas and southeast New Mexico where marine cement and fossils filling fractures indicate early fracturing (Saller, 1996; Kosa \& Hunt, 2006). The Capitan reef also shows a conjugate fracture set oriented perpendicular to the shelf margin. The fractures parallel to the Capitan reef front are generally steeper than Clino, and are concentrated in reefal facies. Differential compaction and basinward tilting (extension) are invoked to explain the steep axial fractures (Saller, 1996; Harwood \& Kendall, 1999; Hunt et al., 2003; Stanton \& Pray, 2004). Although a different setting, this Permian example suggests that early cementation (in this case the reef margin) can fracture relatively early under load-related influences. In the case of Clino, the affect of down-to-the-basin compaction is hard to assess (in core), but perhaps the preferential fracture dip direction to the basin (west) (Figure 8) might be explained by this influence. 


\section{Conclusions}

Studies of fracturing within prograding carbonates are relatively rare. In one example, Saller (1996) and others describe fractures within the reefal facies of the Capitan that have dip directions normal to the depositional strike of the platform margin. The Capitan fractures range between $75^{\circ}$ and $85^{\circ}$ and were interpreted to have formed because of extension during down-tothe-basin differential compaction. The Bahamas fractures may have also experienced some of the same differential compaction, but fracturing was likely driven largely by the loading effects of the overlying, rapidly-emplaced prograded sediment that accumulated on the seaward (basin) side of the Clino location. We propose that this fracturing formed during a period of tectonic quiescence on Great Bahama Bank and is thus essentially non-tectonic in origin.

The Clino fracture data support a non-tectonic mechanism for the formation of macroscopic fractures. The combination of early diagenesis (cementation) and the subsequent load emplacement by the prograding platform margin have produced very early fracturing in the burial history of the platform. These fractures (at least for their early burial history) have distinct geophysical log signatures, and have largely remained opened and unfilled (except for some celestite infill). The original porosity, or later re-opened fracture porosity, may act as major fluidflow pathways within the platform margin slope. Those pathways may be conduits for the upward movement of burial fluids and focus diagenetic alteration associated with those burial fluids. In the deeper subsurface, associated fracture permeability may enhance vertical and lateral fluid flow.

\section{Acknowledgements}

We first and foremost want to thank Robert Ginsburg for his longstanding drive and leadership to make the Bahamas Drilling Project a reality. The U.S. National Science Foundation supported this project, both the drilling and subsequent analyses (OCE 8917295 and OCE 9104294). We also thank the Industrial Associates of the Comparative Sedimentology Lab for providing funds for core collection and (continued) analysis. The Donors to the American Chemical SocietyPetroleum Research Fund (25818-AC8) supported DFM. The work of Jeroen Kenter, Peter Swart and Leslie Melim provided the framework critical to interpreting the Clino fractures, and we thank them for their input. We are grateful to David Olgaard for conducting the uniaxial deformation experiments on Clino core samples while at ETH-Zurich. Harry Elderfield's lab at Cambridge University kindly provided the Sr data on the celestite in collaboration with Peter 
Swart (Univ. of Miami). We thank Al Hine for suggesting a possible role of early fracture on the collapse of platform margins. Art Saller and Taury Smith provided thoughtful review and constructive comments on this manuscript.

\section{References}

Berggren, W.A., Kent, D.V., Swisher, C.C. III and Aubry, M.-P. (1995) A revised Cenozoic geochronology and chronostratigraphy. In: Geochronology Times Scales and Global Stratigraphic Correlation (Eds. W.A. Berggren, D.V. Kent, and M.-P., Aubry) SEPM Spec. Publ., 54, 129-212

Eberli, G.P., and Ginsburg, R.N. (1987) Segmentation and coalescence of platforms, Tertiary, NW Great Bahama Bank. Geology, 15, 75-79.

Eberli, G.P., Anselmetti, F., Kenter, J.A.M., McNeill, D.F., Ginsburg, R.N., Swart, P.K. and Melim, L.A. (2001) Facies, diagenesis, and timing of prograding sequences on western Great Bahama Bank. In: Subsurface Geology of a Prograding Carbonate Platform Margin, Great Bahama Bank: Results of the Bahamas Drilling Project (Ed. R.N. Ginsburg) SEPM Spec. Pub. 70, 241-265.

Ginsburg, R.N. (2001) Subsurface Geology of a Prograding Carbonate Platform Margin, Great Bahama Bank: Results of the Bahamas Drilling Project, SEPM Spec. Pub. 70, 271 pp.

Harwood, G.M., and Kendall, A.C. (1999) Reef margin collapse, gully formation and filling within the Permian Reef; Carlsbad Caverns, New Mexico, USA. Sedimentology, 46, 443-461.

Hine, A.C., Locker, S.D., Tedesco, L.P., Mullins, H.T., Hallock, P., Belknap, D.F., Gonzales, J.L., Neumann, A.C., and Snyder, S.W. (1992) Megabreccia shedding from modern, low-relief carbonate platforms, Nicaraguan Rise. Geological Society America Bulletin, 104, p. 928-943.

Hunt, D.W., Fitchen, W.M., and Kosa, E. (2003) Syndepositional deformation of the Permian Capitan reef carbonate platform, Guadalupe Mountains, New Mexico, USA, Sedimentary Geology, 154, 89-126.

Kenter, J.A.M., Ginsburg, R.N., and Troelstra, S.R. (2001) Sea-level-driven sedimentation patterns on the slope and margin. In: Subsurface Geology of a Prograding Carbonate Platform Margin, Great Bahama Bank: Results of the Bahamas Drilling Project (Ed. R.N. Ginsburg) SEPM Spec. Pub. 70, 61-100.

Kosa, E., and Hunt, D.W. (2006) Heterogeneity in fill and properties of karst-modified syndepositional faults and fractures; Upper Permian Capitan Platform, New Mexico, U.S.A., J. Sedimentary Research 76, 131-151.

Kulander, B.R., Dean, S.L., and Ward, B.J., Jr. (1990) Fractured core analysis: interpretation, logging, and use of natural and induced fractures in core. AAPG Methods in Exploration Series 8, Tulsa, Oklahoma, 88 pp. 
Malone, M.J., Slowey, N.C., and Henderson, G.M. (2001) Early diagenesis of shallow-water periplatform carbonate sediments, leeward margin, Great Bahama bank (Ocean Drilling Program Leg 166). Geological Soc. America Bulletin, 113, 881-894.

McArthur, J.M., Howarth, R.J., and Bailey, T.R. (2001) Strontium isotope stratigraphy: LOWESS Version 3: Best fit to the marine Sr-isotope curve for 0-509 Ma and accompanying look-up table for deriving numerical ages. The Journal of Geology, 109, 155-170.

McNeill, D.F. (1997) Facies and early diagenetic influence on the depositional magnetization of carbonates. Geology, 25, 799-802.

McNeill, D.F. (2005) Accumulation rates from well-dated late Neogene carbonate platforms and margins. Sedimentary Geology, 175, 73-87.

McNeill, D.F., Eberli, G.P., Lidz, B.H., Swart, P.K., and Kenter, J.A.M. (2001)

Chronostratigraphy of a prograded carbonate platform margin: A record of dynamic slope sedimentation, western Great Bahama Bank. In: Subsurface Geology of a Prograding Carbonate Platform Margin, Great Bahama Bank: Results of the Bahamas Drilling Project (Ed. R.N. Ginsburg), SEPM Spec. Pub., 70, 241-265.

Melim, L.K., Swart, P.K., and Maliva, R.G. (2001) Meteoric and marine-burial diagenesis in the subsurface of Great Bahama Bank. In: Subsurface Geology of a Prograding Carbonate Platform Margin, Great Bahama Bank: Results of the Bahamas Drilling Project (Ed. R.N. Ginsburg) SEPM Spec. Pub. 70, 137-161.

Paterson, M.S. (1978) Experimental Rock Deformation-The Brittle Field. Springer-Verlag, Berlin, 254 pp.

Saller, A.H. (1996) Differential compaction and basinward tilting of the prograding Capitan reef complex, Permian, west Texas and southeast New Mexico, USA. Sedimentary Geology, 101, 2130 .

Stanton, R.J., and Pray, L.C. (2004) Skeletal-carbonate neptunian dikes of the Capitan Reef; Permian, Guadalupe Mountains, Texas, U.S.A. J. Sedimentary Research, 74, 805-816.

Swart, P.K., Elderfield, H., and Beets, K. (2001) The ${ }^{87} \mathrm{Sr} /{ }^{86} \mathrm{Sr}$ ratios in carbonates, phosphorites, and fluids collected during the Bahamas Drilling Project cores Clino and Unda: Implications for dating and diagenesis. In: Subsurface Geology of a Prograding Carbonate Platform Margin, Great Bahama Bank: Results of the Bahamas Drilling Project (Ed. R.N. Ginsburg), SEPM Spec. Pub. 70, 175-185.

Westphal, H., and Munnecke, A. (1997) Mechanical compaction versus early cementation in fine-grained limestones: differentiation by the preservation of organic microfossils. Sedimentary Geology, 112, 33-42. 


\section{Figure Captions}

Figure 1. Map showing the location of core Clino on the western margin of Great Bahama Bank. The location of the seismic line on which the line drawing (Figure 2) is based is also shown.

Figure 2. Line drawing of the seismic sequences penetrated by core Clino (from Eberli et al. 2001). Clino fractures occur in sequence $e$ (bounded by red lines). Fractures in sequence $e$ occur primarily in beds of coarse skeletal sediment redeposited downslope from a shallow-water source area east of core Unda. The shaded areas indicate onlapping packages.

Figure 3. Photographs of fracture core. a-b) through-going shear fracture at $441 \mathrm{~m}$ depth; c) axial fracture at $379 \mathrm{~m}$, note central fracture with small subfractures radiating outward; d) cataclastic shear fracture with a central through-going shear, $431 \mathrm{~m}$ depth; e) cataclastic fracture at a bed contact at $437 \mathrm{~m}$; celestite infill of larger fracture openings, this photo illustrates how minor differences in the degree of cementation likely affect fracture potential; f) fracture surface with large crystals of celestite at $401 \mathrm{~m}$ depth.

Figure 4. Histogram of inclination angles for the whole fracture interval in core Clino. The domination by intermediate to vertical fractures suggests compressional and perhaps some extensional forces are influencing the fracture formation.

Figure 5. Fracture plane angle versus depth. The skeletal "interruptions" exhibit a wide scatter in inclination, but most are in excess of $30^{\circ}$. Note that relatively few fractures occur in the hemipelagic intervals.

Figure 6. Cumulative fracture length (total fracture length in centimetres) per $3 \mathrm{~m}$ interval. A slight trend of decreased fracture density with depth can be observed in these histogram plots. This trend may be a result of greater cementation at the sequence boundaries that cap the upper and lower interval, or simply related to the higher permeability in the skeletal "interruptions".

Figure 7. Sonic velocity and caliper logs over the fracture interval. The fractures show greater velocity than the adjacent hemipelagic sediments, a result of greater cementation. Likewise, the caliper log reflects a smaller diameter borehole in the skeletal interruptions relative to the less cemented hemipelagic intervals.

Figure 8. Attitude of the fracture surfaces (dip angle from the horizontal) in Clino as determined by paleomagnetic orientation. The conjugate fractures reflect an orientation perpendicular to the platform margin, with the majority of the fractures dipping seaward.

Figure 9. Age-depth plot for core Clino from McNeill et al. (2001). The upper, middle, and lower fracture intervals are shown in middle Pliocene age host sediments. Progradation loading above SSB-D in the latest Pliocene rapidly added over $300 \mathrm{~m}$ of sediment on top of the skeletal "interruptions" to produce compression fractures.

Figure 10. A cartoon summarizing the general forces and fracture types at the progradational margin of western Great Bahama Bank. The key to early fracture is the preferential early cementation of the skeletal "interruption" beds. 


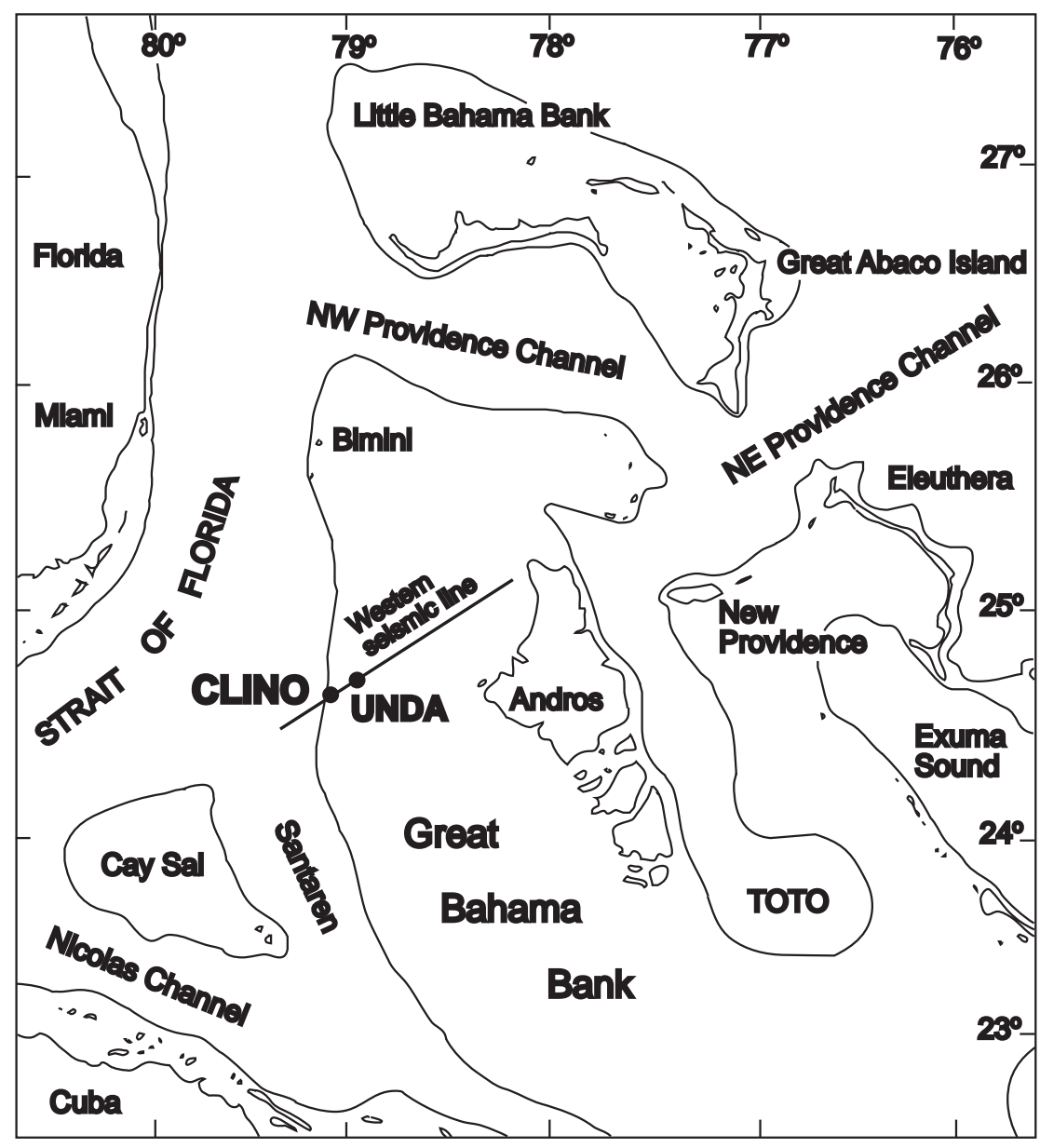

McNeill \& Eberli Figure 1 


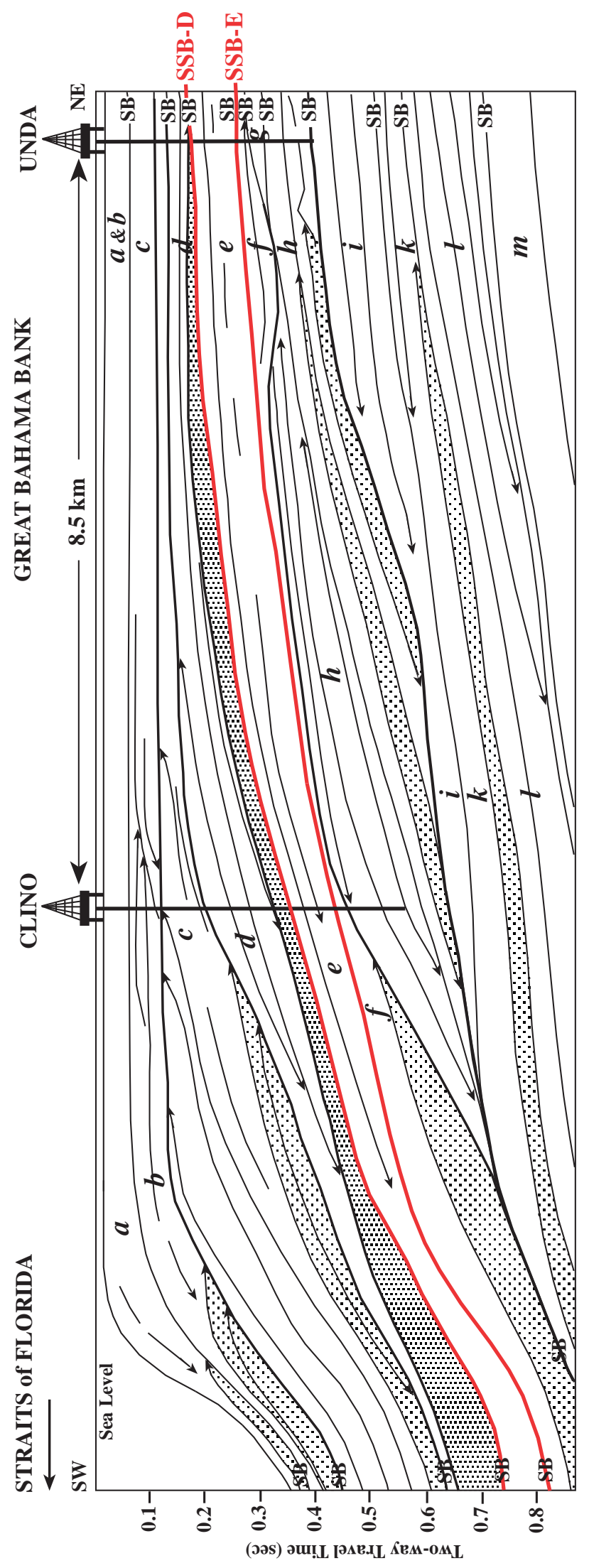

McNeill \& Eberli, Figure 2 

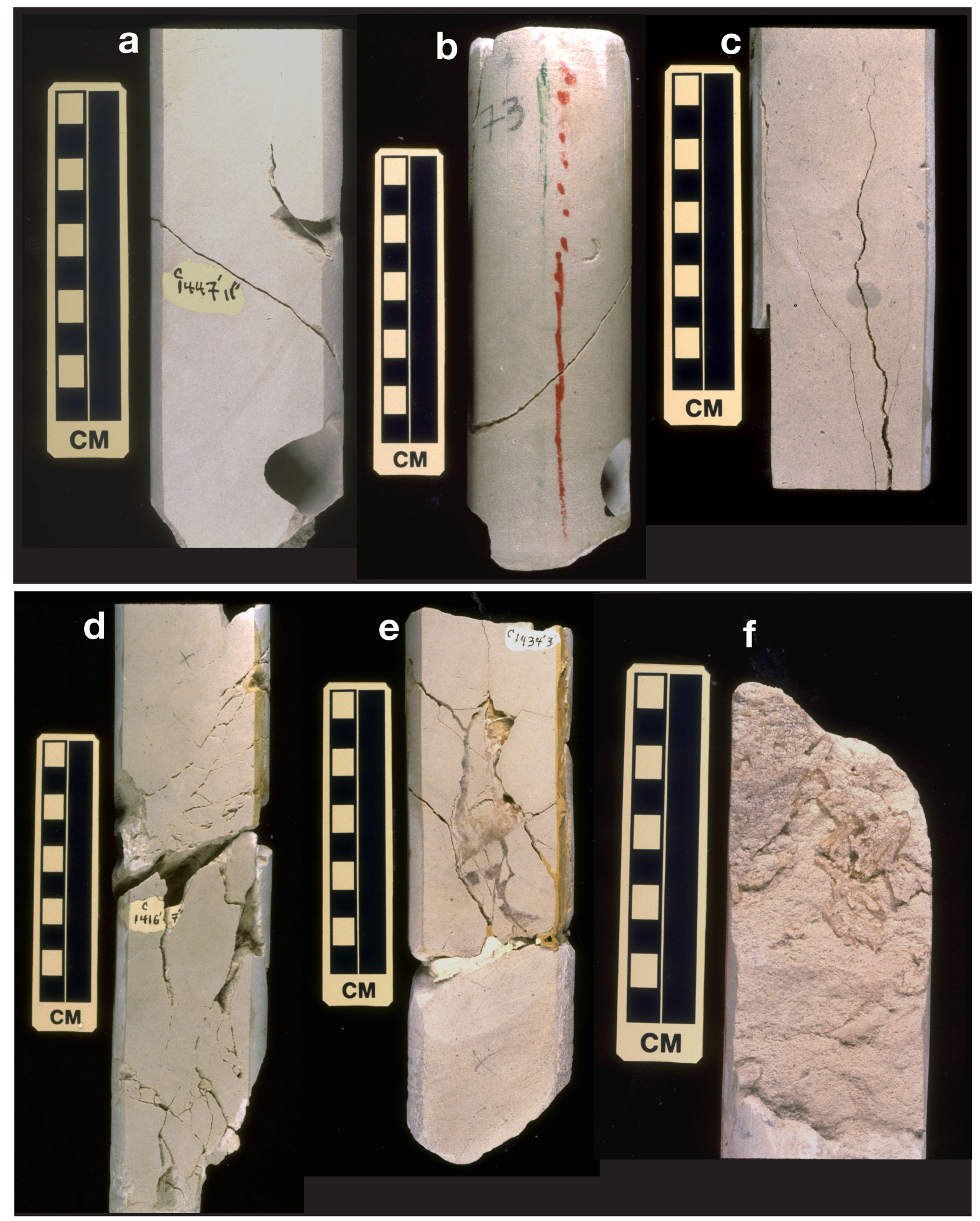

McNeill \& Eberli Figure 3 


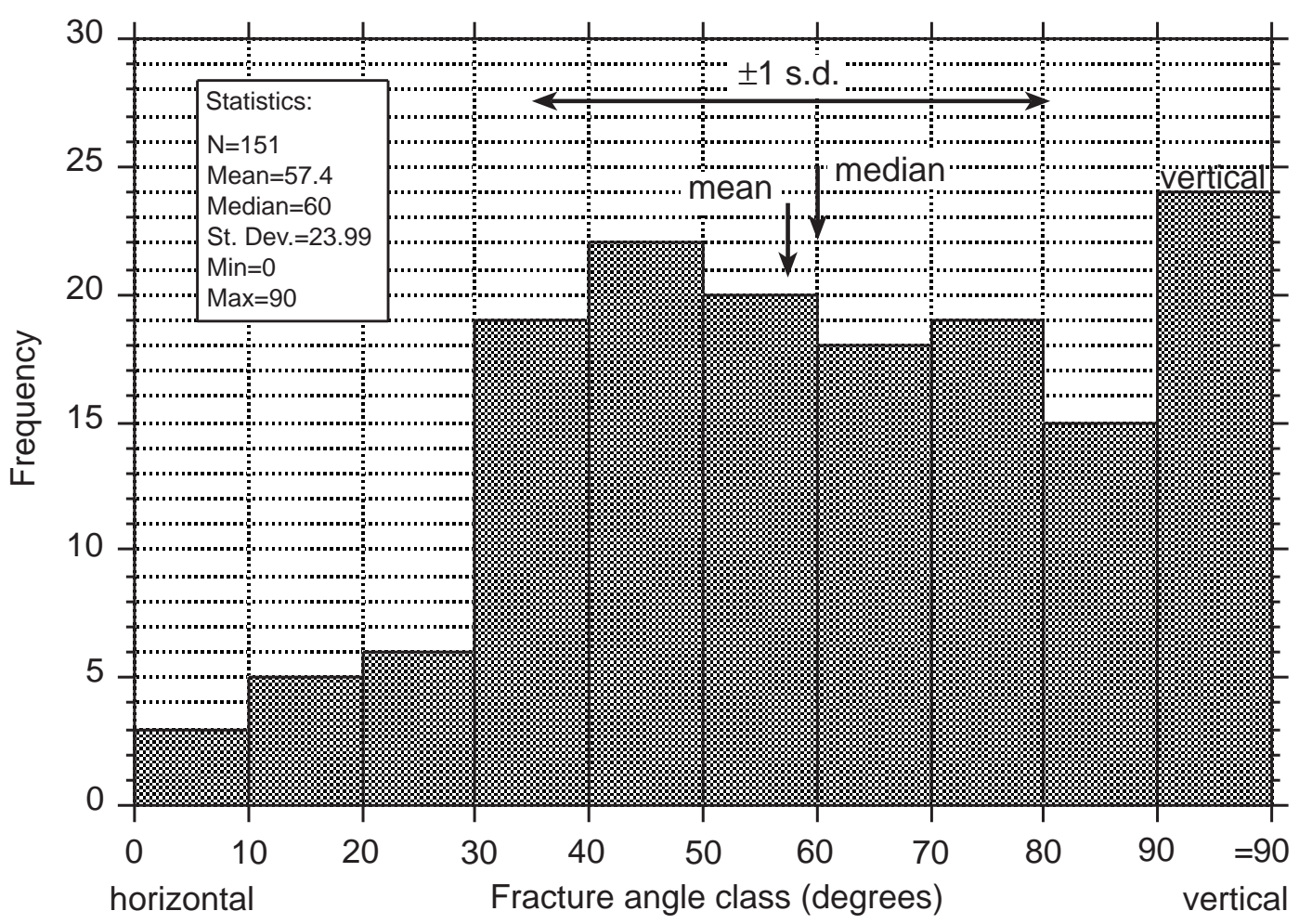

McNeill \& Eberli Figure 4 


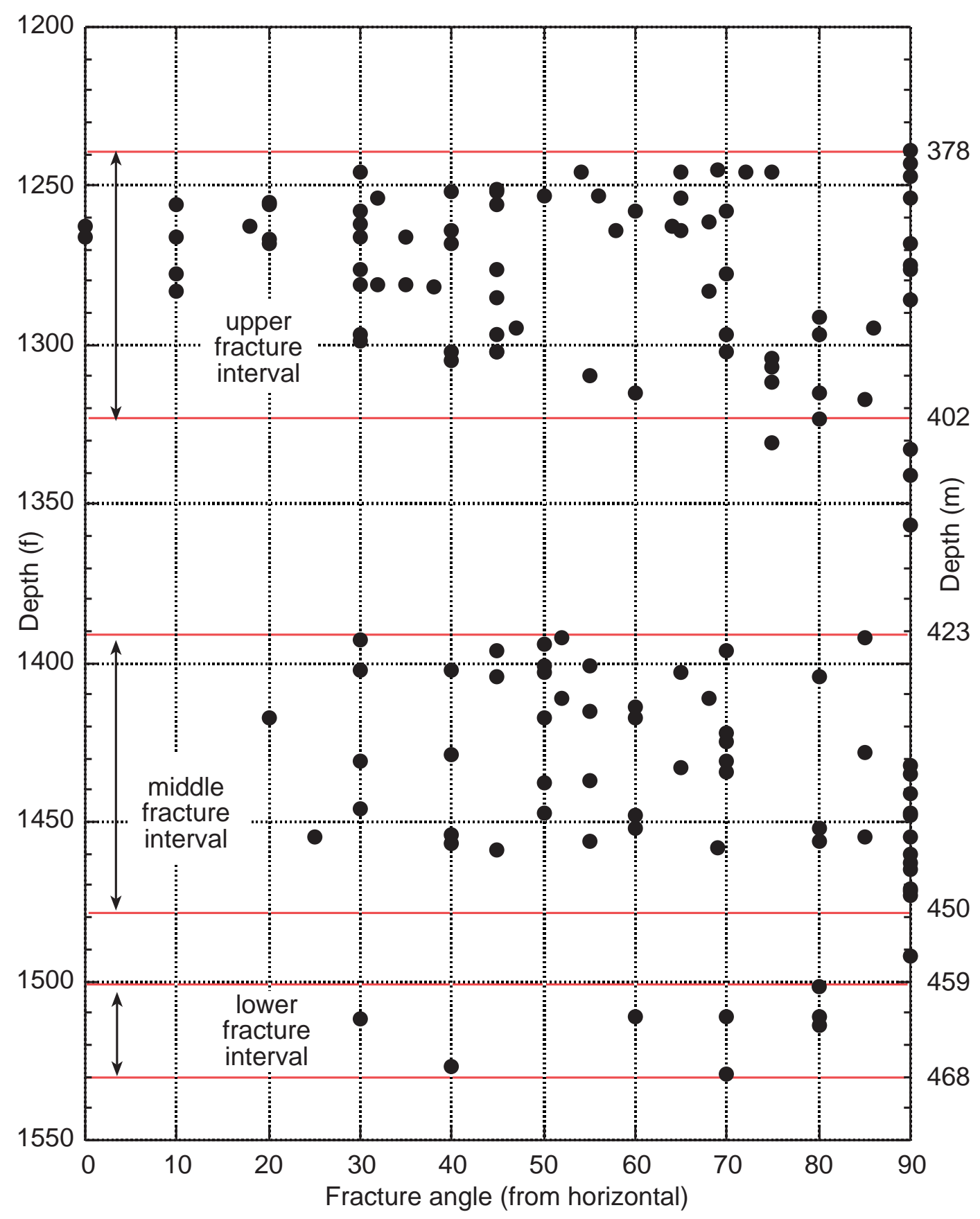

McNeill \& Eberli Figure 5 


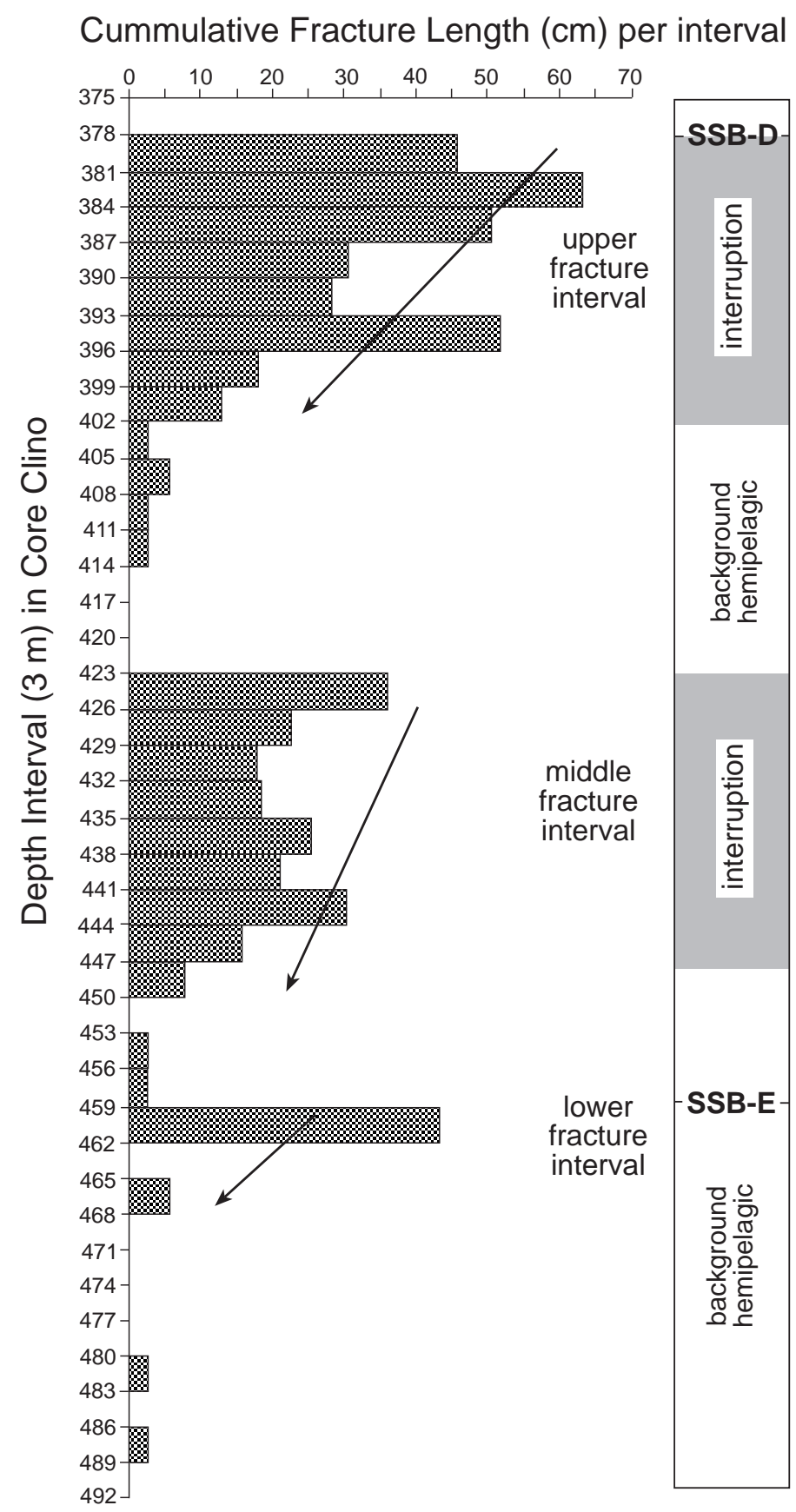

McNeill \& Eberli Figure 6 


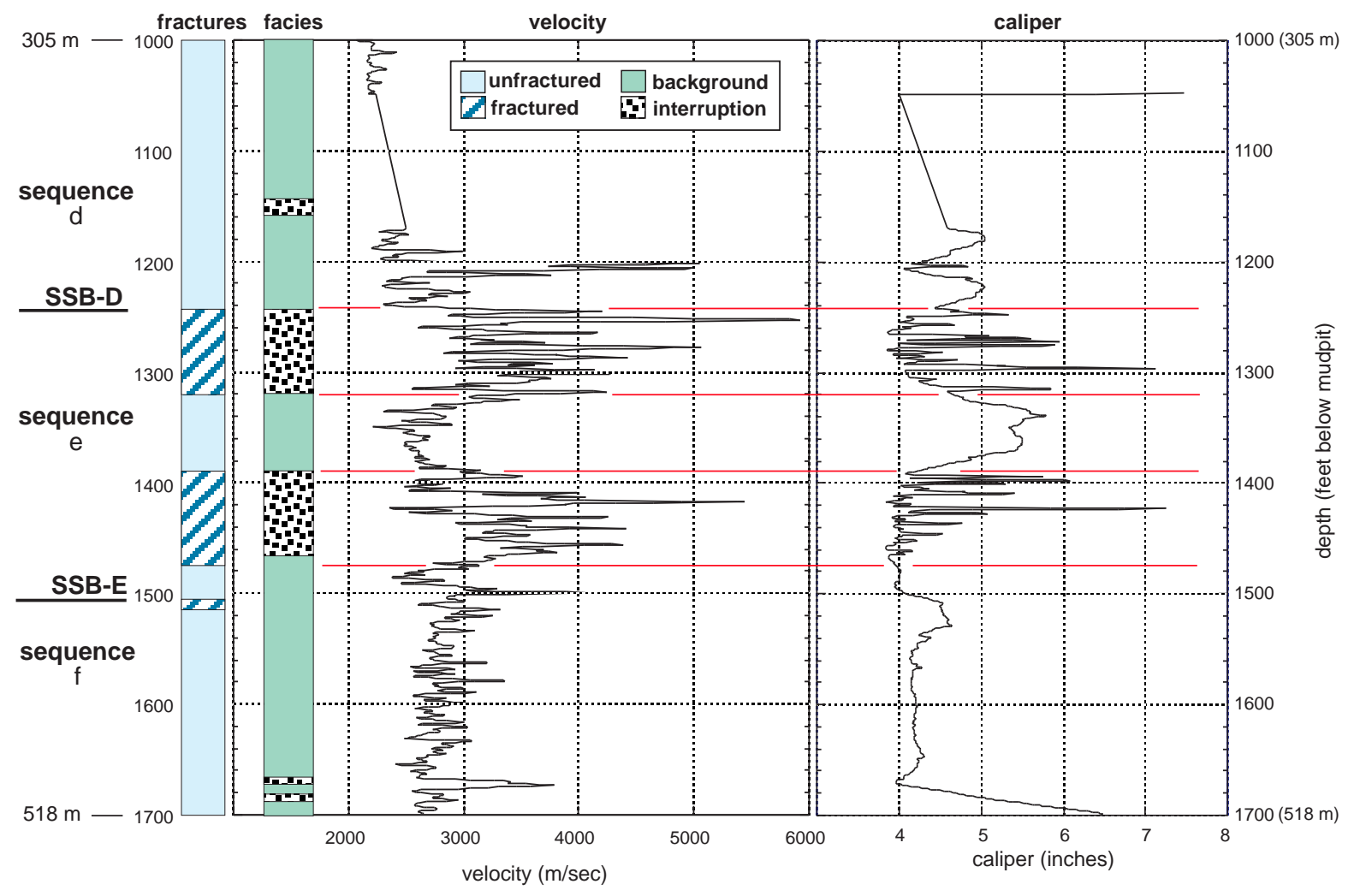

McNeill \& Eberli Figure 7 


\section{Attitude of fracture surfaces \\ Bahamas Drilling Project Core CLINO}

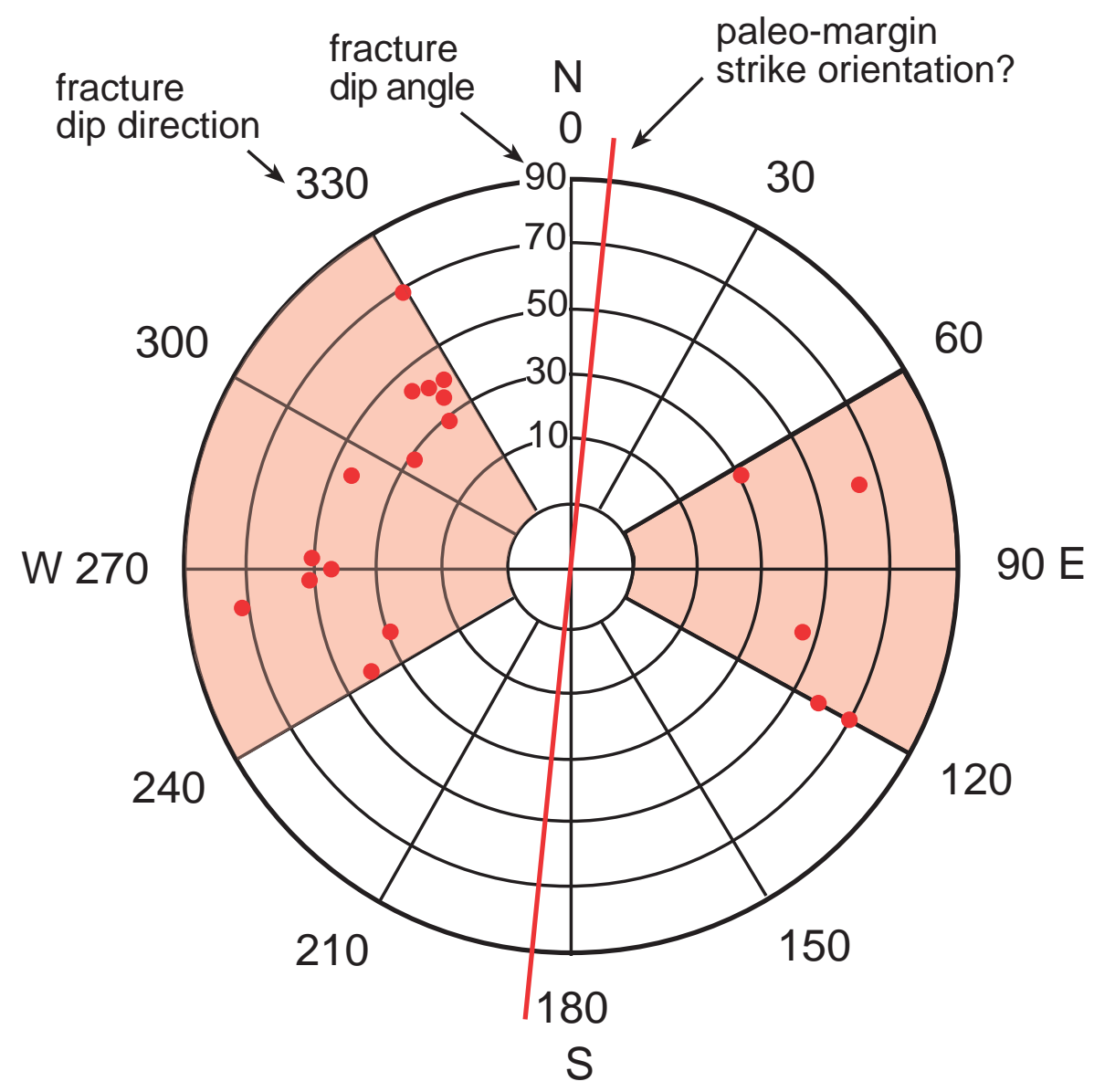

McNeill \& Eberli Figure 8 


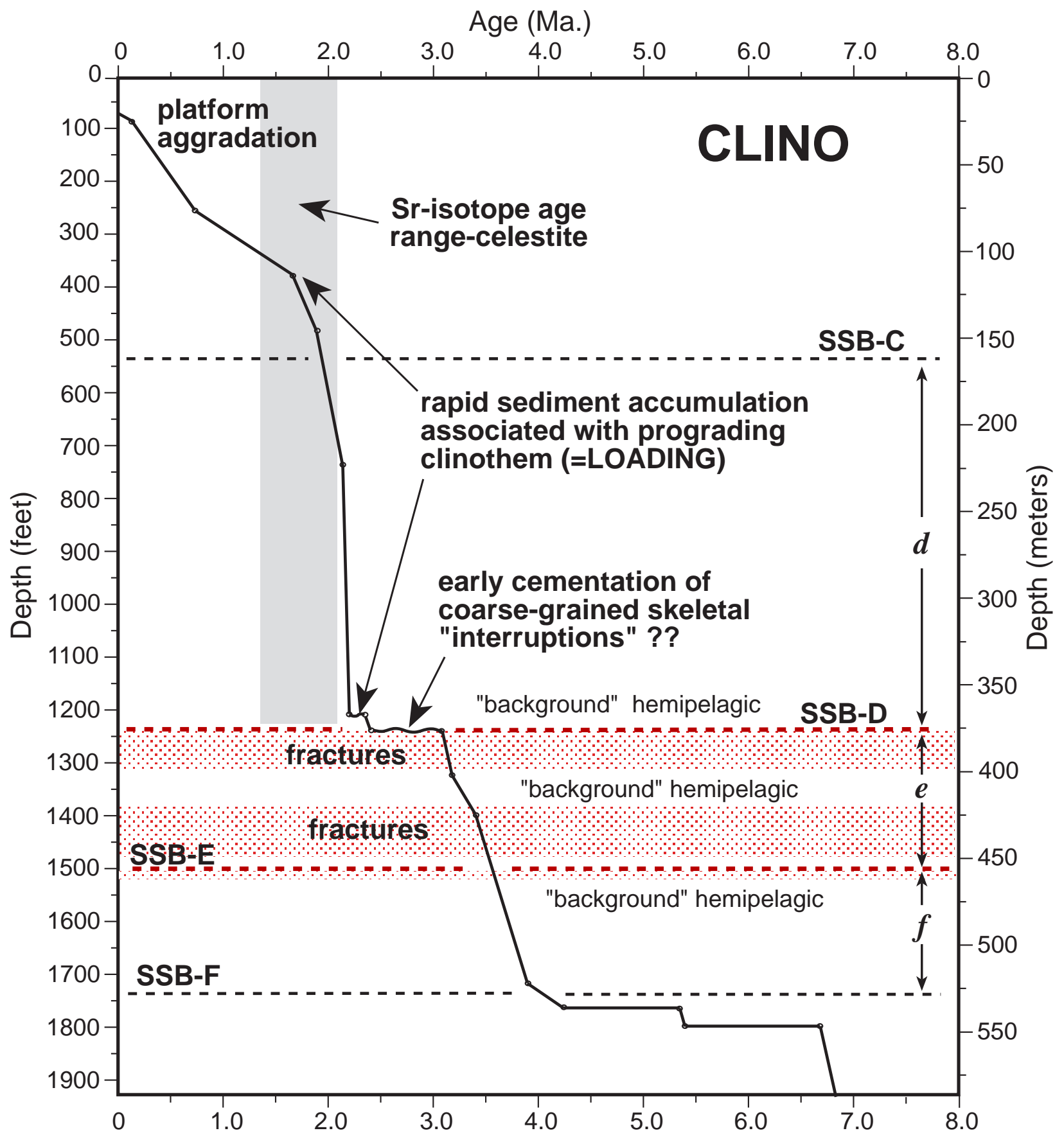

McNeill \& Eberli Figure 9 


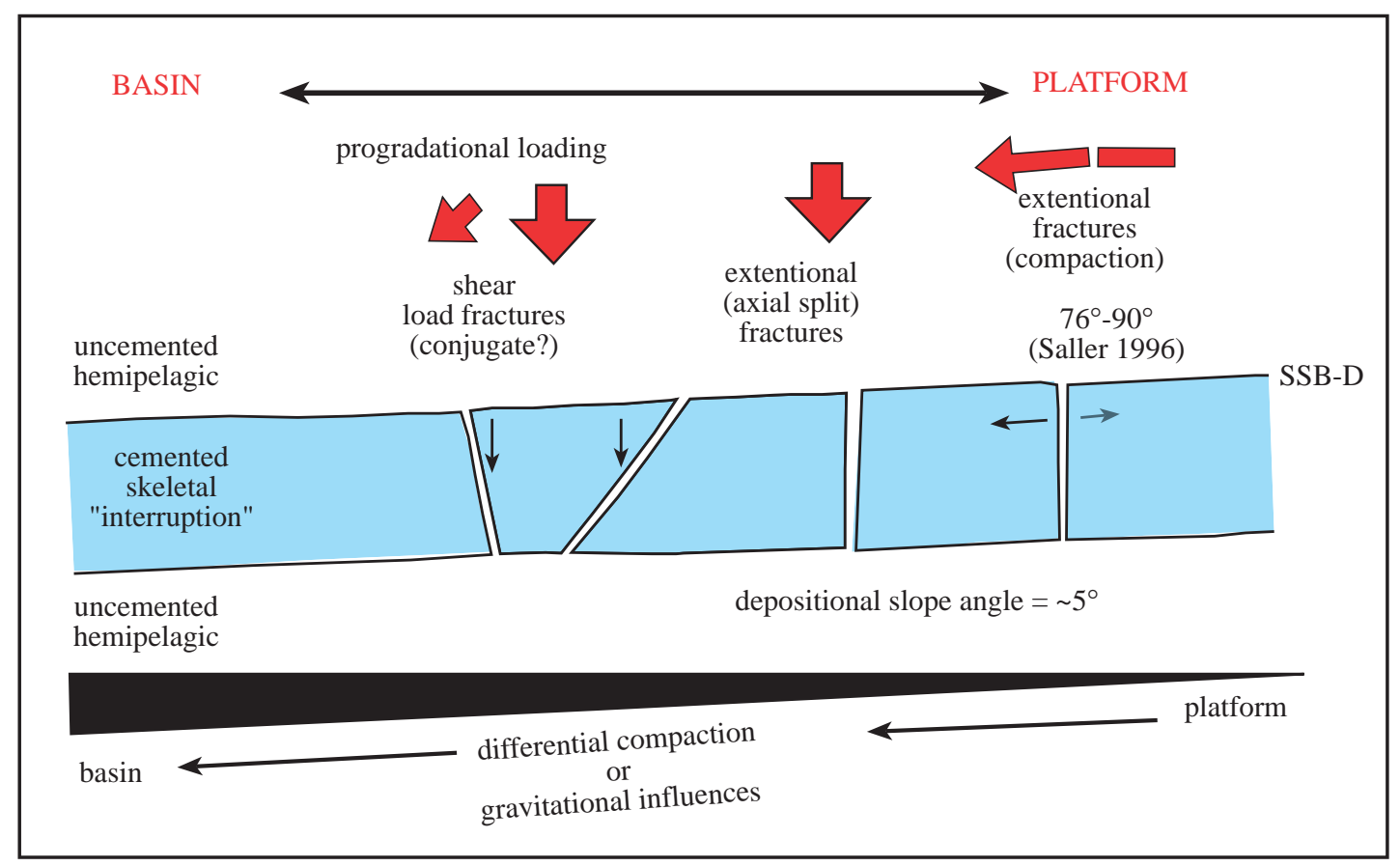

McNeill \& Eberli Figure 10 